\title{
Protective effect of green tea extract against cadmium-induced testicular damage in rats in respect of oxidant/antioxidant equilibrium and androgen production
}

\author{
Basma El-Desoky Barghout, Shimaa Abd El-Salam El-Sayed*, El-Said El-Shirbini El-Said \\ Department of Biochemistry and Chemistry of Nutrition, Faculty of Veterinary Medicine, Mansoura University, 35516, Mansoura, Egypt
}

\section{ARTICLE HISTORY}

Received: 03.11.2019

Revised: 12.03 .2020

Accepted: 14.03 .2020

Address correspondence to Shimaa Abd El-Salam El-Sayed; Tel: +201019475232; E-mail: abdo_dr_shimaa@yahoo.com

\section{ABSTRACT}

Objective: Investigating the effect of green tea extract (GTE) on the testicular damage induced by cadmium chloride $\mathrm{CdCl}_{2}$ in male rats.

Design: Randomized controlled study.

Animals: 40 male Wistar rats.

Procedures: Rats were randomly divided into four groups: A) control group (each rat daily received pellet diet); B) GTE group each rat daily received pellet diet as well as $3 \mathrm{ml}$ of 1.5 $\%$ w/v GTE, C) $\mathrm{CdCl}_{2}$ group each rat was $\mathrm{I} / \mathrm{P}$ injected a single dose of $1 \mathrm{mg} / \mathrm{kg} \mathrm{CdCl}_{2}$, then daily received pellet diet, and D) $\mathrm{CdCl}_{2}+\mathrm{GTE}$ group each rat was $\mathrm{I} / \mathrm{P}$ injected a single dose of $1 \mathrm{mg} / \mathrm{kg} \mathrm{CdCl}$ then daily received pellet diet as well as $3 \mathrm{ml}$ of $1.5 \% \mathrm{w} / \mathrm{v} \mathrm{GTE}$. After 30 days, blood samples were collected for hormonal assays (testosterone, FSH, and LH). In addition, both testes were collected; one of them was used for quantification of 17-beta hydroxysteroid dehydrogenase III (17ß-HSDIII) gene expression using a real-time PCR. The other testis was used for determination of catalase and reduced glutathione; GSH, Nitric oxide (NO) and malondialdehyde (MDA) levels.

Results: $\mathrm{CdCl}_{2}$ decreased serum testosterone levels and its synthesis pathway (17ß-HSDIII testicular gene expression). While antioxidants catalase and GSH were reduced, oxidants MDA were enriched in the testes of $\mathrm{CdCl}_{2}$-poisoned rats. This $\mathrm{CdCl}_{2}$-promoted testicular dysfunction was corrected via the administration of GTE to male rats.

Conclusion and clinical relevance: GTE could be used as a remedy for protecting against $\mathrm{CdCl}_{2}$-induced testicular damage in male rats.

Keywords: Cadmium, Green tea, testosterone, antioxidants, testes

\section{INTRODUCTION}

Although its utilization in the manufacture of metal plating, batteries, plastics as well as fertilizers, cadmium chloride $\left(\mathrm{CdCl}_{2}\right)$ is classified as an environmental pollutant having the ability to pollute the water and soil and therefore could easily transfer to the plants [1]. As a result, consumption of such polluted water and/or foods could induce $\mathrm{CdCl}_{2}$ toxicity. It has been reported that $\mathrm{CdCl}_{2}$ toxicity could lead to many heal th problems even though the exposure to relatively low doses of $\mathrm{CdCl}_{2}$. This might be referred to the cumulative effect of $\mathrm{CdCl}_{2}$ in the biological systems of the body [2].

Among thes e biological systems, the reproductive system has been found to be severely affected by the exposure to $\mathrm{CdCl}_{2}$. In regards to ma les, ei ther acute or chronic $\mathrm{CdCl}_{2}$ toxicity has been linked with poor semen quality and defective androgen production [3]. This is possibly due to the capability of $\mathrm{CdCl}_{2}$ to produce reactive oxygen species (ROS) and thereby disturbing the pro-oxidants/antioxidants' equilibrium leading to oxidative stress (OS) [4]. Recently, the oxidative stress has been shown to have a destructive effect on the bloodtes ticular barrier in male rats due to the accumulation of lipid peroxidation (LPO) in many organs of male rats including testes and subsequently infertility problem(s) was raised in male rats as a result of $\mathrm{CdCl}_{2}$ toxicity $[5,6]$.

In the last few decades, a much more interest has been paid for using naturally occurring dietary substances like medicinal plants in order to manage various health problems including infertility [7]. Green tea (Camellia sinensis), a member of the Theaceae family, seems to be a good choice for overcoming $\mathrm{CdCl}_{2}$-induced infertility; green tea flavonoid epigallocatechin-3-gallate (EGCG) is a classified as a potent antioxidant and thus it could prevent OS through combating ROS over production [8]. Lately in Nigeria, it has 
been recorded that green tea supplementation reduced the cadmium level and regulated the levels of sex hormones in automobile workers [9]. Here, we aimed to inves tigate the effect of green tea extract on the testicular da mage induced by $\mathrm{CdCl}_{2}$ in male rats.

\section{MATERIALS AND METHODS}

\subsection{Animals and Experimental design}

Wistar a lbino a dult ( 10 weeks old) male rats $(n=40)$, each rat weighted about $250 \pm 50 \mathrm{~g}$, were obtained from Medical Experimental Research Center (MERC), Mansoura University, Egypt. To be adapted with the environmental conditions before conduction of the experimental design, rats were housed for one week in clear stainless cages ( 5 rats/ cage) at $22 \pm 4{ }^{\circ} \mathrm{C}$ room temperature and $55 \pm 10 \%$ relative humidity. Afterwards, rats were randomly divided into four groups: A) control group (each rat daily received pel let di et according to National Res earch Council, NRC for 30 days) [10], B) GTE group (each rat daily received pel let diet as well as $3 \mathrm{ml}$ of $1.5 \% \mathrm{w} / \mathrm{v}$ GTE by a stoma ch tube for 30 days) [11], C) $\mathrm{CdCl}_{2}$ group (each rat was I/Pinjected a single dose of $1 \mathrm{mg} / \mathrm{kg} \mathrm{CdCl}_{2}$, then daily received pellet diet for 30 days) [12], and D) $\mathrm{CdCl}_{2}+\mathrm{GTE}$ group (each rat was / P injected a single dose of $1 \mathrm{mg} / \mathrm{kg} \mathrm{CdCl}{ }_{2}$ then daily received pellet diet as well as $3 \mathrm{ml}$ of $1.5 \% \mathrm{w} / \mathrm{v}$ GTE by a stomach tube for 30 days).

\subsection{Preparation of GTE}

For GTE preparation, 250 grams of green tea leaves purchased from a local market were ground and extracted by ethanol (80\%) in a separating funnel. The extract was concentrated using a rotary evaporator, then kept in sealed vials in a freezer until use. The percentage of extract was calculated according to the dry matter of the green tea. To make $1.5 \%$ w/v GTE, GTE (15 g.) was dissolved in one liter distilled water, boiled for 5 minutes, then filtered [13].

\subsection{Blood sampling}

After 30 days, all rats were fasted overnight before their seda tion via the injection of thiopental sodium $25 \mathrm{mg} / \mathrm{kg}$ [14]. Afterwards, the blood was collected from the heart; the sa mples were left overnight at $4^{\circ} \mathrm{C}$ to clot, centrifuged at 3000 rpm for $15 \mathrm{~min}$, and then the clear serum was collected and kept in freezer $\left(-18^{\circ} \mathrm{C}\right)$ for measuring testosterone hormone level using rat Tes tosterone ELISA kit (DRG Instruments $\mathrm{GmbH}$, Germany) [15], follicle stimulating hormone (FSH) level using rat FSH ELISA kit (Biovendor Res earch and Diagnostic Products, Germany) [16] and luteinizing hormone (LH) level using rat $\mathrm{LH}$ ELISA Kit (BioVendor Research AND Diagnostic Products, Germany) [17].

\subsection{Tissue sampling}

Five rats from each group were sacrificed for obtain both testes. One testis was dissected for testicular tissues which then stored in RNA storage solution at $-20^{\circ} \mathrm{C}$ for SYBR Green real-time polymerase chain reaction (PCR). The other testis was us ed for preparation of tissue homogenate. In brief, it was perfused with phosphate-buffered saline (PBS, pH 7.4), then homogenized in $5-10 \mathrm{ml}$ cold buffer $(50 \mathrm{mM}$ potassium phos phate, pH 7.5)/each g. tissue. After that, samples were centrifuged at 4000 r.p.m. for 15 min., sediments were discarded, and supernatants were taken, stored at $-20^{\circ} \mathrm{C}$ for determination of catalase activity [18], reduced glutathione (GSH) level [19], Nitric oxide (NO) level [20] malondialdehyde (MDA) level [21].

\subsection{Quantitative real-time $P C R$}

Total RNA was extracted from testes tissue (RNeasy Mini Kit; QIAGEN Company) according to the manufacturer's instructions. Total RNA was spectrophotometrically quantified. The gene expression of testicular 17-beta hydroxysteroid dehydrogenase III (17 $\beta$-HSDIII) was determined using a quantitative real-time PCR. Simply, a total $25 \mu \mathrm{l}$ reaction mix consisting of $12.5 \mu \mathrm{l}$ Quanti Tect SYBR Green PCR Master Mix (QIAGEN, Hilden, Germany), $8.5 \mu \mathrm{l}$ RNase Free water (Invitrogen, California, USA), Reverse transcriptase, $0.5 \mu \mathrm{l}$ of forward and reverse primer $(20 \mathrm{pmol})$, and $3 \mu \mathrm{l}$ of RNA sample. The reverse transcription was done at $50^{\circ} \mathrm{C}$ for $30 \mathrm{~min}$. After that, the amplification program was run: 40 cycles with primary denaturation at $94^{\circ}$ for $15 \mathrm{~min}$, secondary denaturation at $94^{\circ} \mathrm{C}$ for $1 \mathrm{~min}$, primer annealing at $60^{\circ} \mathrm{C}$ for $30 \mathrm{sec}$, followed by extension at $72^{\circ} \mathrm{C}$ for $30 \mathrm{sec}$. $\beta$-actin was us ed as housekeeping gene. Oligonucleotide PCR primers used for rat $\beta$-actin [22] and 17 $\beta$-HSDIII [23] are shown in Table 1.

\subsection{Statistical analysis}

Statistical analysis of the collected, validated, and organized data was performed using $\mathrm{IBM}^{\circ}$ SPSS $^{\circ}$ Statistics 14 (IBM Corp., Armonk, NY, USA). One-way ANOVA followed by Duncan multiple comparison test was used to compare means. Data are presented as mean \pm standard error of the mean (SEM). The results were considered statistically significant at $P$ $<0.05$.

\section{RESULTS}

3.1. Effect of GTE, $\mathrm{CdCl}_{2}$ and GTE with $\mathrm{CdCl}_{2}$ on the blood levels of testosterone hormone, FSH, and $\mathrm{LH}$

A marked decrease of testosterone hormone, $\mathrm{FSH}$, and $\mathrm{LH}$ was detected in the blood levels of male rats injected with $\mathrm{CdCl}_{2}$ when compared with the control rats. These hormones were significantly increased via GTE adminis tration in $\mathrm{CdCl}_{2-}$ poisoned rats (Table 2). 


\subsection{Effect of GTE, $\mathrm{CdCl}_{2}$ and $\mathrm{GTE}$ with $\mathrm{CdCl}_{2}$ on testicular antioxidants and OS markers}

$\mathrm{CdCl}_{2}$ significantly reduced testicular antioxidants (ca talase a ctivity and GSH level) and upregulated tes ticular OS markers (MDA levels) while GTE administration noticeably improved catalase activity and GSH level with diminishing MDAlevel in the testicular tissues of $\mathrm{CdCl}_{2}$-intoxicated rats (Table 3).

\subsection{Effect of GTE, $\mathrm{CdCl}_{2}$ and GTE with $\mathrm{CdCl}_{2}$ on testicular 178- HSDIII gene expression}

$\mathrm{CdCl}_{2}$-intoxicated rats that were administered GTE had an obvious upregulation of tes ticular 17 $\beta$-HSDIII gene expression when compared with those were not given GTE (Table 4).

Table 1. The sequence of primers us ed for the real-time PCR.

\begin{tabular}{ll} 
Genes & Primer sequence $\left(5^{\prime}-3^{\prime}\right)$ \\
\multirow{3}{*}{-actin } & Forward 5-T CCT CCTG AGCGCAAGTACTC T-3 \\
\cline { 2 - 2 } & Reverse 5-GCTCAGTAACAGTCCGCCTAGA A-3 \\
\hline 17ß-HSDIII & Forward 5-CCT GAG ATCAAT GGG ACA ATG-3 \\
\cline { 2 - 2 } & Reverse 5-CCC TACTCC CGA AGA GAT A-3
\end{tabular}

Table. 2. Effect of $\mathrm{GTE}, \mathrm{CdCl} 2$ and $\mathrm{GTE}$ with $\mathrm{CdCl} 2$ on the blood levels of testosterone hormone, FSH, and LH.

\begin{tabular}{|c|c|c|c|}
\hline \multirow{2}{*}{ Groups } & \multicolumn{3}{|c|}{ Serum Levels of hormones $(\mathrm{ng} / \mathrm{ml})$} \\
\hline & Testosterone & FSH & LH \\
\hline Control & $2.06 \pm 0.06^{\mathrm{a}}$ & $5.77 \pm 0.13^{\mathrm{a}}$ & $3.56 \pm 0.16^{\mathrm{a}}$ \\
\hline GTE & $2.03 \pm 0.10^{\mathrm{a}}$ & $5.53 \pm 0.22^{\mathrm{a}}$ & $4.11 \pm 0.17^{\mathrm{a}}$ \\
\hline $\mathrm{CdCl}_{2}$ & $0.99 \pm 0.03^{c}$ & $1.72 \pm 0.13^{c}$ & $1.20 \pm 0.10^{c}$ \\
\hline $\mathrm{GTE}+\mathrm{CdCl}_{2}$ & $1.57 \pm 0.14^{b}$ & $3.00 \pm 0.13^{b}$ & $2.11 \pm 0.13^{b}$ \\
\hline
\end{tabular}

Table 3. Effect of GTE, $\mathrm{CdCl}_{2}$ and GTE with $\mathrm{CdCl}_{2}$ on testicular antioxidants and OS markers.

\begin{tabular}{|c|c|c|c|c|}
\hline \multirow[b]{2}{*}{ Groups } & \multicolumn{2}{|c|}{ Antioxidants } & \multicolumn{2}{|c|}{ OS markers } \\
\hline & $\begin{array}{c}\text { Catalase } \\
\text { activity } \\
\text { (U/g tissue) }\end{array}$ & $\begin{array}{c}\text { GSH levels } \\
\text { (mg/g } \\
\text { tissue) }\end{array}$ & $\begin{array}{c}\text { MDA levels } \\
\text { ( } \mu \mathrm{mol} / \mathrm{g} \\
\text { tissue) }\end{array}$ & $\begin{array}{c}\text { NO levels } \\
\text { ( } \mu \mathrm{mol} / \mathrm{g} \\
\text { tissue) }\end{array}$ \\
\hline Control & $0.33 \pm 0.02^{\mathrm{a}}$ & $2.18 \pm 0.36^{b}$ & $2.69 \pm 0.52^{\mathrm{ab}}$ & $21.0 \pm 3.52^{b}$ \\
\hline GTE & $0.36 \pm 0.05^{\mathrm{a}}$ & $4.02 \pm 0.37^{a}$ & $1.63 \pm 0.51^{c}$ & $33.01 \pm 8.60^{b}$ \\
\hline $\mathrm{CdCl}_{2}$ & $0.04 \pm 0.01^{b}$ & $0.42 \pm 0.08^{c}$ & $3.71 \pm 0.55^{\mathrm{a}}$ & $69.78 \pm 6.48^{a}$ \\
\hline $\begin{array}{l}\mathrm{GTE}+\mathrm{Cd} \\
\mathrm{Cl}_{2}\end{array}$ & $0.42 \pm 0.04^{\mathrm{a}}$ & $0.76 \pm 0.09^{c}$ & $2.07 \pm 0.28^{b}$ & $67.5 \pm 3.67^{\mathrm{a}}$ \\
\hline
\end{tabular}

Table 4. Effect of $\mathrm{GTE}, \mathrm{CdCl}_{2}$ and $\mathrm{GTE}$ with $\mathrm{CdCl}_{2}$ on testicular $17 \beta$-HSDIII gene expression.

\begin{tabular}{l|cccc}
\hline Groups & Control & GTE & $\mathrm{CdCl}_{2}$ & $\mathrm{GTE}+\mathrm{CdCl}_{2}$ \\
\hline $\begin{array}{l}\text { 17ß-HSDIII gene } \\
\text { expression }\end{array}$ & $\begin{array}{l}1.19 \pm \\
0.08^{\mathrm{bc}}\end{array}$ & $\begin{array}{l}2.49 \pm \\
0.16^{\mathrm{a}}\end{array}$ & $\begin{array}{l}0.69 \pm \\
0.05^{\mathrm{c}}\end{array}$ & $\begin{array}{l}1.80 \pm \\
0.13^{\mathrm{ab}}\end{array}$ \\
*Results were expressed as mean \pm standard error of the mean (S.E.M). \\
Different letters denote a significant variance (P<0.05).
\end{tabular}

\section{DISCUSSION}

The existing work used a simplified rat model for evaluating the efficiency of herbal medicines, definitely GTE, in ameliorating the adverse effects of $\mathrm{CdCl}_{2}$ toxicity on the male reproductive organs, in particular testes. Indeed, supplementation of GTE for $\mathrm{CdCl}_{2}$-intoxicated male rats restored the blood levels of sex hormones through readjustment of the pro-/anti-oxidant balance in the testicular tissue.

To begin with, testosterone is the principle male sex hormone produced by the interstitial cells of testes under the effect of $\mathrm{LH}$. The functionality of both hormones, in addition to FSH, is crucial for regulation of spermatogenesis process $[24,25]$. Consequently, assessing the blood levels of such hormones is a vital indicator for testicular competence

The current study showed that blood levels of tes tos terone, $\mathrm{LH}$, and FSH hormones were reduced in case of $\mathrm{CdCl}_{2}$ intoxication. In accordance with our result, previous studies demonstrated that free radicals, especially ROS, produced after $\mathrm{CdCl}_{2}$ injection could destroy the precursors of tes tos terone through lipid peroxidation of testicular interstitial cells' membranes thereby impairing androgen production in these cells $[26,27]$.

Importantly, GTE giving to $\mathrm{CdCl}_{2}$-intoxicated male rats brought back the physiological plateau of the above sex hormones. In the sameline, former investigations pointed out that GTE minimized the testicular damage in male rats exposed to $\mathrm{CdCl}_{2}$ [28]. Likewise, GTE had a positive impact on the amount of gona dotropin hormones ( $\mathrm{LH}$ and FSH) in female rats poisoned with $\mathrm{CdCl}_{2}$ [29].

To explore the mechanism whereby GTE could upregulate the blood levels of sex hormones, particularly tes tosterone, it was es sential to investigate the gene expression of $17 \beta-H S D I I$, the key player of testosterone synthesis [30]. It was evident that $\mathrm{CdCl}_{2}$ had an inhibitory effect on $17 \beta-\mathrm{HSDIII}$ gene expression in the tes ticular tissues; this effect was reversed by GTE administration to poisoned rats. In the same line, it was found cyclophosphamide, an immunosuppressive agent, could induce testicular damage in male mice. However, the pretreatment of these mice with green tea infusion rescued them. To be more precise, green tea infusion strengthened the 
antioxidant capacity and increased the activity of $17 \beta$-HSDIII in the testicular tissues [31].

Of known that ROS production, at the physiological levels, is ess ential for some sperm functions (like maturation, hyperactivation, capacitation as well as acquiringferti lizing ability). However, excessive ROS production in the expense of antioxidant capacity (i.e. OS status) could lead to LPO and subs equently DNA damage and a poptosis [32]. Accordingly, it was necessary to assess oxidants/anti-oxidants' equilibrium system in $\mathrm{CdCl}_{2}$-intoxicated testes of male rats in presence/absence of GTE. Interestingly, our biochemical analyses revealed an obvious reduction in the testicular activity of a ntioxidants markers (catalase and GSH) in response to $\mathrm{CdCl}_{2}$ exposure. Catalase is an intracellular enzyme capable of splitting hydrogen peroxide $\left(\mathrm{H}_{2} \mathrm{O}_{2}\right)$ into water and oxygen [33]. A similar study referred the reduced catalase a ctivity and the consequent $\mathrm{H}_{2} \mathrm{O}_{2}$ accumulation to the decreased iron (Fe) absorption in the stressed tissues [34]; Fe is an es sential trace el ement for the functionality of catalase enzyme [35]. On the other hand, the declined GSH activity was attributed to the ability of $\mathrm{CdCl}_{2}$ to bind with $\mathrm{SH}$ group in the cell membrane with a subsequent inactivation of such antioxidant member [12].

Based on the above findings, we expected that the lower antioxidant levels could result in higher levels of LPO in the testicular tissues of $\mathrm{CdCl}_{2}$-intoxicated rats when compared with control ones. Actually, MDA as end product LPO of pol yunsaturated fatty acids was el evated in rat tes tes exposed to $\mathrm{CdCl}_{2}$. In the same direction, some reports showed that a single-dose administration of $\mathrm{CdCl}_{2}$ increased LPO levels in the form of MDA [36].

Alongside ROS, reactive nitrogen species (RNS) are classified as potent free radicals. Among them, NO is intra cellularly synthetized by the action of NO synthases (NOS) [37]. Clearly, our da ta revealed a big rise in NO tes ticular levels in rats poisoned with $\mathrm{CdCl}_{2}$. This coincides with the fact that the activity of NOS increases in case of the stressed tes tes like cryptorchidism [38].

Depending on its antioxidant properties [8], GTE was administered $\mathrm{CdCl}_{2}$-poisoned rats for diminishing the severity of OS problem. In such manner, GTE not only enhanced the antioxidant levels but also weakened the progression of LPO process in the testiculartissues. Notably, similar studies were conducted in the liver and kidney; they also found that GTE could prevent the hepatic- and renal da mage induced by $\mathrm{CdCl}_{2}$ poisoning in rats through the inhibition of LPO $[39,40]$.

The current study showed that NO level did not meaningfully change by GTE treatment in rats exposed to $\mathrm{CdCl}$. However, another study proved that the consumption of green tea could negatively affect NO levels [41]. The explanation of such findings based on the ability of green tea flavonoid (EGCG) to suppress NO-production system via the inhibition of NOS gene expression in target tissues. Besides, EGCG is capable of promoting NO-scavenging system. Al together, EGCG could mitigate the excess NO levels [42].

\section{Conclusion}

To sum up, GTE could be us ed as a remedy for protecting against $\mathrm{CdCl}_{2}$-induced testicular da mage in male rats

\section{Acknowledgment}

\section{Conflict of interest statement}

The a uthors declare that there is no conflict of interest in the current research work.

\section{Animal Ethics Committee Permission}

The current research work was permitted to be executed according to standards of a nimal res earch committee in the Faculty of Veterinary Medicine, Mansoura University, Egypt.

\section{Authors' contributions}

B. E. conducted the experiment and a nalytical procedures and drafted the manuscript, S. E. performed statistical analysis and revised the manuscript, E. E. revised the manuscript.

\section{REFERENCES}

[1] Satarug S, Garrett SH, Sens MA, Sens DA. Cadmium, environmental exposure, and health outcomes.J Environ Health Perspect 2010;118:182-190. https://doi.org/10.1289/ehp.0901234

[2] Imafidon C, Akomolafe R, Sanusi A, Ogundipe O, Olukiran O, Ayowole O. Polyphenol-rich extract of Vernonia amygdalina (del.) leaves ameliorated cadmium-induced alterations in feeding pattern and urine volume of male Wistar rats. J Intercult Ethnopharmacol 2015;4:284-292. https://doi.org/10.5455/jice.20151107021034

[3] Wirth JJ, Mijal RS. Adverse effects of low level heavy metal exposure on male reproductive function. J Syst Biol Reprod Med 2010;56:147-167. https://doi.org/10.3109/19396360903582216

[4] Tremellen K. Oxidative stress and male infertility-a clinical perspective. J Hum Reprod Update 2008;14:243-258. https://doi.org/10.1093/humupd/dmn004

[5] Minutoli L, Micali A, Pisani A, Puzzolo D, Bitto A, Rinaldi M, Pizzino G, Irrera N, Galfo F Arena S, Pallio G, Mecchio A, Germana A, Bruschetta D, Laura R, Magno C, Marini H, Squadrito F, Altavilla D. Flavocoxid protects against cadmium-induced disruption of the blood-testis barrier and improves testicular damage and germ cell impairment in mice. J Toxicol Sci 2015;148:311-329. https://doi.org/10.1093/toxsci/kfv185

[6] Sharma P, Goyal PK. Ameliorative Effect of Green Tea Catechin against Cadmium Chloride-Induced Testicular Toxicity in Mice. J Environ Pathol Toxicol Oncol 2015; 34:335-352. https://doi.org/10.1615/JEnvironPatholToxicolOncol.2015011903

[7] Winiarska-Mieczan A. The potential protective effect of green, black, red and white tea infusions against adverse effect of cadmium and lead during chronic exposure-A rat model study. J Regul Toxicol Pharmacol 2015;73:521-529. https://doi.org/10.1016/j.yrtph.2015.10.007

[8] Agarwal A, Sharma RK, Nallella KP, Thomas AJ, Alvarez JG, Sikka SC. Reactive oxygen species as an independent marker of male factor infertility. J Fertil Steril 2006;86:878-885 https://doi.org/10.1016/j.fertnstert.2006.02.111 
[9] Nwando OE, Emmanuel DC, Chukwuemeka MS, Joy OI, Opeyemi US. Effect of Green Tea Supplementation on Blood Cadmium and Male Sex Hormone Levels in Automobile Workers in Emene, Enugu State, Nigeria. J Adv Med Med Res

2018;5:1-7.

\section{https://doi.org/10.9734/JAMMR/2018/42879}

[10] National Research Council. Nutrient requirements of laboratory animals. National Academies Press 1995.

[11] El-Shahat AE-R, Gabr A, Meki A-R, Mehana E-S. Altered Testicular Morphology and Oxidative Stress Induced by Cadmium in Experimental Rats and Protective Effect of Simultaneous Green Tea Extract. Int J Morphol 2009;27:757-764. https://doi.org/10.4067/s071795022009000300020

[12] de Souza Predes F, Diamante MA, Dolder H. Testis response to low doses of cadmium in Wistar rats. Int J Exp Pathol 2010;91:125-31. https://doi.org/10.1111/j.1365-2613.2009.00692.x

[13] Maity S, Vadasiromoni J, Ganguly D. Role of glutathione in the antiulcer effect of hot water extract of black tea. Jpn J Pharmacol 1998;78:285-92. https://doi.org/10.1254/jjp.78.285

[14] Vdoviaková K, Petrovová E, Maloveská M, Krešáková L, Teleky J, Elias MZ, Petrášová D. Surgical Anatomy of the Gastrointestinal Tract and Its Vasculature in the Laboratory Rat. J. Gastroent Res Pract 2016;1-11. https://doi.org/10.1155/2016/2632368

[15] Akomolafe SF, Olasehinde TA, Ogunsuyi OB, Oyeleye SI, Oboh G. Caffeine improves sperm quality, modulates steroidogenic enzyme activities, restore testosterone levels and prevent oxidative damage in testicular and epididymal tissues of scopolamine-induced rat model of amnesia. J Pharm Pharmacol 2019;71:1565-1575. https://doi. org/10.1111/jphp.13142

[16] Kumar V, Chakraborty A, Kural MR, Roy P. Alteration of testicular steroidogenesis and histopathology of reproductive system in male rats treated with triclosan. J Reprod Toxicol 2009;27:177-185. https://doi.org/10.1016/j.reprotox.2008.12.002

[17] Awodele O, Badru WA, Busari AA, Kale OE, Ajayi TB, Udeh RO, Emeka PM. Toxicological evaluation of therapeutic and supra-therapeutic doses of Cellgevity ${ }^{\circledast}$ on reproductive function and biochemical indices in Wistar rats. J BMC Pharmacol Toxicol 2018;19:68. https://doi.org/10.1186/s40360-018-0253-y

[18] Ajaghaku DL, Obasi O, Umeokoli BO. In vitro and in vivo antioxidant potentials of Alchornea floribunda leaf extract, fractions and isolated bioactive compounds. Avicenna J Phytomed 2017;7:80-92.

[19] Ezhilarasan D, Karthikeyan SJCjonm. Silibinin alleviates Nnitrosodimethylamine-induced glutathione dysregulation and hepatotoxicity in rats. Chin J Nat Med 2016; 14:40-47.

[20] Csonka C, Páli T, Bencsik P, Görbe A, Ferdinandy P, Csont T. Measurement of NO in biological samples. Br J Pharmacol 2015;172:1620-1632. https://doi.org/10.1111/bph.12832

[21] Khoubnasabjafari M, Ansarin K, Jouyban AJBB. Reliability of malondialdehyde as a biomarker of oxidative stress in psychological disorders. J Bioimpacts 2015;5:123-127. https://doi.org/10.15171/bi.2015.20

[22] Banni M, Messaoudi I, Said L, El Heni J, Kerkeni A, Said K. Metallothionein Gene Expression in Liver of Rats Exposed to Cadmium and Supplemented with Zinc and Selenium. J Arch Environ Contam Toxicol 2010;59:513-519. https://doi.org/10.1007/s00244-010-9494-5

[23] Tena-Sempere M, Barreiro ML, González LC, Gaytán F, Zhang FP, Caminos JE, Pinilla L, Casanueva FF, Diéguez C, Aguilar E. Novel Expression and Functional Role of Ghrelin in Rat Testis. Endocrinology 2002;143:717-725. https://doi.org/10.1210/endo.143.2.8646

[24] Manna I, Jana K, Samanta PK. Effect of intensive exerciseinduced testicular gametogenic and steroidogenic disorders in mature male Wistar strain rats: a correlative approach to oxidative stress. Acta Physiol Scand 2003;178:33-40. https://doi.org/10.1046/j.1365201X.2003.01095.x

[25] Figueroa V, Pippi Salle JL, Braga LH, Romao R, Koyle MA, Bägli DJ, Lorenzo AJ. Comparative analysis of detorsion alone versus detorsion and tunica albuginea decompression (fasciotomy) with tunica vaginalis flap coverage in the surgical management of prolonged testicular ischemia. J Urol 2012;188:1417-1422. https://doi.org/10.1016/j.juro.2012.02.017

[26] Monsefi M, Alaee S, Moradshahi A, Rohani L. Cadmium-induced infertility in male mice. Environ Toxicol 2010;25:94102. https://doi.org/10.1002/tox.20468

[27] Ko EY, Sabanegh Jr ES, Agarwal AJF, sterility. Male infertility testing: reactive oxygen species and antioxidant capacity. I Fertil Steril 2014;102:1518-1527. https://doi.org/10.1016/j.fertnstert.2014.10.020

[28] Mahmoudi R, Azizi A, Abedini S, Hemayatkhah Jahromi V, Abidi H, Jafari Barmak M. Green tea improves rat sperm quality and reduced cadmium chloride damage effect in spermatogenesis cycle. J Med Life 2018;11:371380.

[29] Mahmood B, Mokhtar M, Esfandiar S. The impact of green tea (Camelia sinensis) on the amount of gonadotropin hormones (LH, FSH) in immature female rats poisoned with cadmium chloride. Biomed Pharmacol J 2015;8:261-268. https://doi.org/10.13005/bpj/607

[30] Persson B, Kallberg Y, Bray JE, Bruford E, Dellaporta SL, Favia AD, Jörnvall H, Kavanagh KL, Kedishvili N, Kisiela M, Maser E, Mindnich R, Orchard S, Penning TM, Thornton JM, Adamski J, Oppermann U. The SDR (shortchain dehydrogenase/reductase and related enzymes) nomenclature initiative. J Chem Biol Interact 2009;178:94-98. https://doi.org/10.1016/j.cbi.2008.10.040

[31] Zanchi MM, Manfredini V, Brum DdS, Vargas LM, Spiazzi CC, Soares MB, Izaguirry AP, Santos FW. Green tea infusion improves cyclophosphamideinduced damage on male mice reproductive system. I Toxicol Rep 2015;2:252-260. https://doi.org/10.1016/j.toxrep.2014.12.016

[32] Kothari S, Thompson A, Agarwal A, du Plessis SS. Free radicals: their beneficial and detrimental effects on sperm function. Indian J Exp Biol 2010; 48:425-435.

[33] Chelikani P, Fita I, Loewen PC. Diversity of structures and properties among catalases. Cell Mol Life Sci 2004;61:192 208. https://doi.org/10.1007/s00018-003-3206-5

[34] Jurczuk MI, Brzóska MM, Moniuszko-Jakoniuk J, Gałażyn-Sidorczuk M, Kulikowska-Karpińska E. Antioxidant enzymes activity and lipid peroxidation in liver and kidney of rats exposed to cadmium and ethanol. Food Chem Toxicol https://doi.org/10.1016/j.fct.2003.10.005

[35] Aebi H. Catalase in vitro. Methods Enzymol 1984;105:121 126. https://doi.org/10.1016/S0076-6879(84)05016-3

[36] Eleawa SM, Alkhateeb MA, Alhashem FH, Bin-Jaliah I, Sakr HF, Elrefaey HM, Elkarib AO, Alessa RM, Haidara MA, Shatoor AS, Khalil MA. Resveratrol reverses cadmium chloride-induced testicular damage and subfertility by downregulating p53 and Bax and upregulating gonadotropins and Bcl-2 gene expression. J Reprod Develop 2014;60:115-127. https://doi.org/10.1262/jrd.2013-097

[37] Knowles RG, Moncada S. Nitric oxide synthases in mammals. Biochem J 1994; 298:249-258. https://doi.org/10.1042/bj2980249

[38] Ishikawa T1, Kondo Y, Goda K, Fujisawa M. Overexpression of endothelial nitric oxide synthase in transgenic mice accelerates testicular germ cell apoptosis induced by experimental cryptorchidism. J Androl 2005;26:2818. https://doi.org/10.1002/j.1939-4640.2005.tb01096.x

[39] Hamden K, Carreau S, Ellouz F, Masmoudi H, El Feki A. Improvement effect of green tea on hepatic dysfunction, lipid peroxidation and antioxidant defence depletion induced by cadmium. Afr J Biotechnol 2009;8:4233-4238.

[40] Ibrahim NK. Possible protective effect of kombucha tea ferment on cadmium chloride induced liver and kidney damage in irradiated rats. Int J Biol Life Sci 2013;:7-12.

[41] Tsai PJ, Tsai TH, Yu C-H, Ho S-C. Comparison of NO-scavenging and NOsuppressing activities of different herbal teas with those of green tea. Food Chem 2007;103:181-187 https://doi.org/10.1016/j.foodchem.2006.08.013

[42] Tipoe G, Leung T-M, Hung M-W, Fung M-L. Green Tea Polyphenols as an Anti-Oxidant and Anti-Inflammatory Agent for Cardiovascular Protection. J Cardiovasc Hematol Disord : Drug Targets 2007:2:135-144. https://doi.org/10.2174/187152907780830905 